\title{
Aldgamycin I, an antibacterial 16-membered macrolide from the abandoned mine bacterium, Streptomyces sp. KMA-001
}

\author{
Jin-Soo Park, Hyun Ok Yang and Hak Cheol Kwon \\ The Journal of Antibiotics (2009) 62, 171-175; doi:10.1038/ja.2009.6; published online 13 February 2009
}

Keywords: actinomycetes; aldgamycin; antibacterial activity; macrolide; mine microorganism; Streptomyces

\begin{abstract}
Abandoned mines are often extremely contaminated by heavy metals and acid, creating a unique nutrient environment. Nonetheless, it has been recognized that microorganisms have adapted to life in this unique bioregion. ${ }^{1}$ In the harsh conditions of an abandoned mine, microorganisms are likely to be subjected to substantial levels of competition, which could lead them to develop unique chemical arsenals, such as antibiotics. ${ }^{2,3}$ In the course of our study on the production of secondary metabolites by the mine actinomycete, Streptomyces sp. KMA-001 was isolated from a heat-treated soil sample $\left(55^{\circ} \mathrm{C}, 5 \mathrm{~min}\right)$ collected at the Yeonhwa abandoned zinc mine in Korea. From a pure culture of this strain, we have isolated a new aldgamycin derivative, aldgamycin I (1), along with four earlier reported 16-membered macrolides, aldgamycin E (2), ${ }^{4,5}$ aldgamycin $\mathrm{F}(\mathbf{3}){ }^{6}$ aldgamycin $\mathrm{G}(\mathbf{4})^{7}$ and chalcomycin $(\mathbf{5})^{8}$ (Figure 1 ).
\end{abstract}

A stock culture of the strain KMA-001 was maintained on YeastMalt extract (YM) agar containing nystatin $\left(50 \mu \mathrm{g} \mathrm{ml}^{-1}\right)$ to minimize fungal contamination. The YM agar medium consisted of a yeast extract (Difco, Detroit, MI, USA) 0.5\%, a malt extract (Difco) $3.0 \%$ and agar $1.5 \%$. The strain KMA-001 was grown on the YM agar medium for 7 days and was then cultured in $25 \mathrm{ml}$ YM broth medium $(0.5 \mathrm{~g}$ yeast extract (Difco) and $3 \mathrm{~g}$ malt extract (Difco) in $100 \mathrm{ml}$ deionized water) in a 100 -ml erlenmeyer flask for 3 days. The seed culture broth $(25 \mathrm{ml})$ was transferred to a 1-l erlenmeyer flask containing $500 \mathrm{ml} \mathrm{A1BFe}$ broth (pH 6.4 before sterilization) consisting of starch (Difco, $10 \mathrm{~g}$ ), yeast extract (Difco, $4 \mathrm{~g}$ ), peptone (Difco, $2 \mathrm{~g}$ ), $\mathrm{FeSO}_{4} \cdot 7 \mathrm{H}_{2} \mathrm{O}(0.08 \mathrm{~g})$ and $\mathrm{KBr}(0.1 \mathrm{~g})$ in 11 of deionized water for the second culture step. After 3 days, each $25 \mathrm{ml}$ broth from the second culture was inoculated into 25 erlenmeyer flasks of 11 , each containing $500 \mathrm{ml} \mathrm{A1BFe}$ medium, and was cultured at $28^{\circ} \mathrm{C}$ with shaking at 200 r.p.m. for 7 days.

Total genomic DNA preparation of the KMA-001 strain was carried out according to the G-spin Genomic DNA Extraction Kit (iNtRON Biotechnology, Seongnam, Korea). PCR amplification of the 16S
rDNA was performed using two universal primers $27 \mathrm{f}$ ( $5^{\prime}$-AGA GTT TGA TCM TGG CTC AG- $3^{\prime}$ ) and 1492R (5'-TAC GGH TAC CTT GTT ACG ACT T- $\left.3^{\prime}\right) .{ }^{9}$ The PCR mixture consisted of 30 picomoles of each primer, $100 \mathrm{ng}$ of chromosomal DNA, $200 \mu \mathrm{M}$ dNTPs and $2.5 \mathrm{U}$ of Taq polymerase in $50 \mu \mathrm{l}$ of total volume. The amplification was carried out for 35 cycles at $94^{\circ} \mathrm{C}$ for $30 \mathrm{~s}$, annealing at $54^{\circ} \mathrm{C}$ for $30 \mathrm{~s}$ and extension at $72{ }^{\circ} \mathrm{C}$ for $1.5 \mathrm{~min}$. The PCR product was analyzed by agarose gel eletrophoresis and the remaining mixture was purified using a PCR purification kit (Solgent Co., Ltd, Daejeon, Korea). The $16 S$ rDNA PCR product was sequenced by Solgent Co., Ltd. BLAST (http://blast.ncbi.nlm.nih.gov/Blast.cgi) was used to access the DNA similarities. The $16 \mathrm{~S}$ rDNA sequence of KMA-001 strain showed a homology of 99.3\% with Streptomyces goshikiensis NBRC 12868, S. citricolor NBRC 13005 and S. sporoverrucosus NBRC 15458. The cultured strain, KMA-001, was deposited with the Korean Culture Center of Microorganisms (KCCM42921).

The secondary metabolites of this bacterium were analyzed by HPLC-MS using a gradient solvent system, $10-100 \% \mathrm{CH}_{3} \mathrm{CN} /$ water, for $30 \mathrm{~min}$ (flow rate $0.7 \mathrm{ml} \mathrm{min}{ }^{-1}$, column agilent eclipse XDB-C18, $4.6 \times 150 \mathrm{~mm}, 5 \mu \mathrm{m}$ ) daily for 7 days to observe temporal production. Five chromatographic peaks were selected for purification after comparison analysis with our in-house HPLC-MS-UV database. After 7 days of fermentation, $20 \mathrm{gl}^{-1}$ Amberlite XAD-7 adsorbent resin (Supelco, Bellefonte, PA, USA) was added into each 1-1 culture flask (the volume of broth $500 \mathrm{ml} \times 25$ ), and the mixture was shaken for an additional hour. The resin was then collected by filtration through cheesecloth, washed with deionized water and eluted twice with $\mathrm{Me}_{2} \mathrm{CO}$. The crude extract was fractionated by $\mathrm{C} 18$ flash column chromatography using mixtures of $\mathrm{MeOH}$-water (20, 40, 60, 80 and $100 \% \mathrm{MeOH}$ in water, each $200 \mathrm{ml}$, flow rate $20 \mathrm{ml} \mathrm{min}^{-1}$ ) as elution solvents. The $60 \% \mathrm{MeOH}$ fraction contained all the HPLC peaks of interest and was repurified by prep-HPLC with a Luna C18 (2) column $(21.2 \times 250 \mathrm{~mm}, 15 \mu \mathrm{m}$, Phenomenex Inc., Torrance, CA, USA 


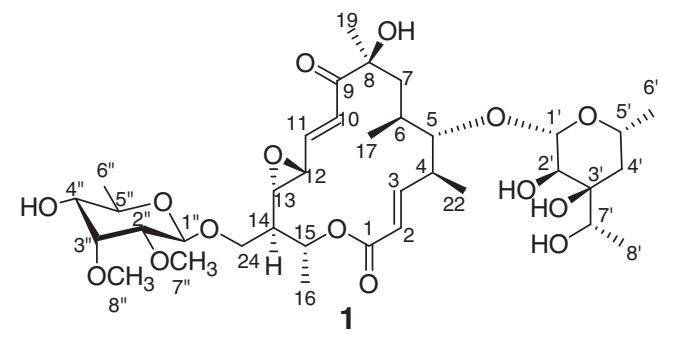

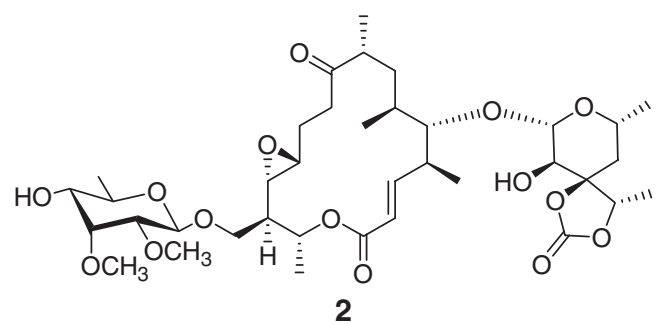

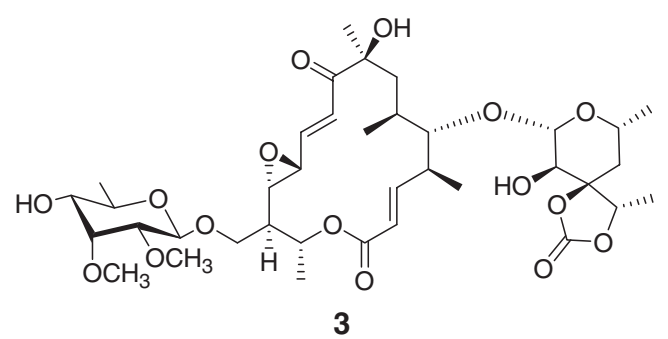

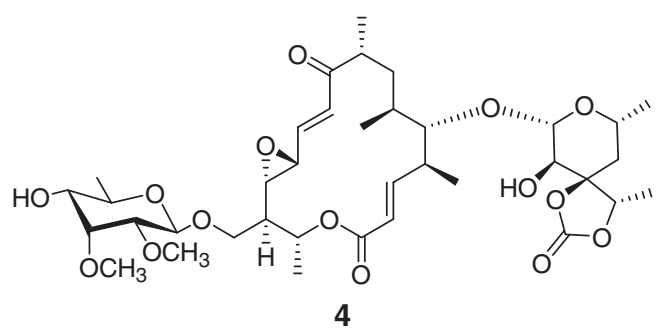

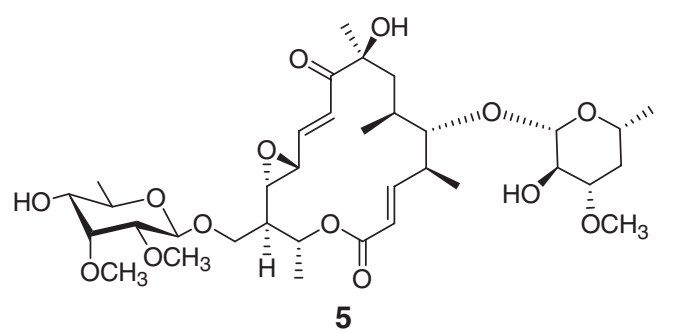

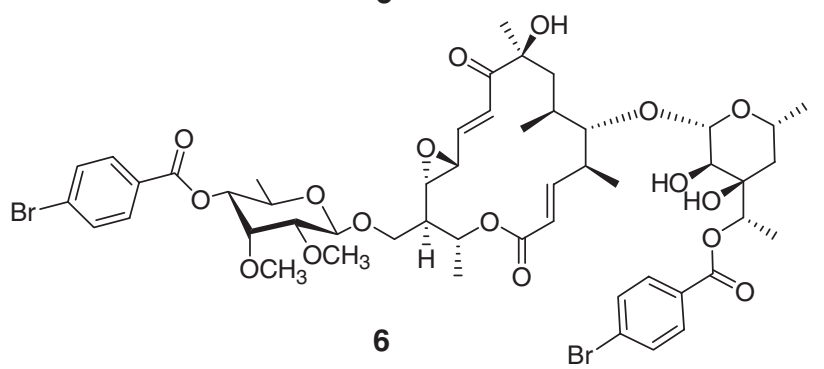

Figure 1 Structures of compounds 1-6.

using an acetonitrile-water $(1.6: 1 \mathrm{v} / \mathrm{v})$ isocratic condition (flow rate $10 \mathrm{ml} \mathrm{min}^{-1}$ ) to yield five 16 -membered macrolides, aldgamycin I $(1,16.0 \mathrm{mg})$, aldgamycin $\mathrm{E}(2,5.4 \mathrm{mg})$, aldgamycin $\mathrm{F}(3,4.0 \mathrm{mg})$, aldgamycin $\mathrm{G}(4,3.5 \mathrm{mg})$ and chalcomycin $(5,12.0 \mathrm{mg})$.
Aldgamycin I (1) was obtained as a white amorphous powder. The molecular formula was assigned to be $\mathrm{C}_{36} \mathrm{H}_{58} \mathrm{O}_{15}$ by HR-FAB-MS $\left((\mathrm{M}+\mathrm{Na})^{+}=753.3668\right),{ }^{1} \mathrm{H}$ and ${ }^{13} \mathrm{C}$ NMR data (Table 1$)$. The observed IR absorptions at 1709 and $1235 \mathrm{~cm}^{-1}$ showed the presence of $\alpha, \beta$ unsaturated carbonyl and epoxide functionalities (Table 2), which were confirmed by the presence of an ester carbonyl carbon at $\delta_{\mathrm{C}}$ 165.6 and oxygenated carbons at $\delta_{\mathrm{C}} 58.7$ and 59.1 in the ${ }^{13} \mathrm{C} \mathrm{NMR}$ spectrum. Comparison of ${ }^{13} \mathrm{C}$ NMR spectra of 1 and 3 was essentially identical except for C-3', C-4', C-7' and C-8' (1: $\delta 74.8,37.1,70.0$, and 16.7, aldgamycin F: $\delta 85.0,40.7,81.5$ and 13.0). Comprehensive NMR analysis, using data from HSQC, HMBC, ${ }^{1} \mathrm{H}-{ }^{1} \mathrm{H}$ COSY and ${ }^{1} \mathrm{H}-{ }^{1} \mathrm{H}$ TOCSY experiments allowed us to assign the structure of $\mathbf{1}$, which contained a decarboxylated D-aldgaroside, 4,6-dideoxy-3-C-(1-hydroxyethyl)- $\beta$-D-ribo-hexopyranose, instead of the $D$-aldgarose in earlier reported aldgamycin F (3). Aldgamycin I (1) was so named because aldgamycin $\mathrm{H}$, an 8-dehydroxy derivative of 1 , was described in an earlier French patent. ${ }^{10}$

The absolute configuration of $\mathbf{1}$ was determined mainly by comparison of the $\mathrm{CD}$ spectral data of aldgamycin I (1) and aldgamycin $\mathrm{F}$ (3). Treatment of $\mathbf{1}$ and $\mathbf{3}$ (each $0.5 \mathrm{mg}$ ) in dry pyridine $(1 \mathrm{ml}$ ) with dimethylaminopyridine $(0.5 \mathrm{mg})$ and 4-bromo benzoyl chloride $(2 \mathrm{mg})$ at room temperature for $12 \mathrm{~h}$, in separate experiments, yielded the reaction mixture including, $7^{\prime}, 4^{\prime \prime}$-di-O-p-bromobenzoyl-aldgamycin I (6; Figure 1). Compound $\mathbf{6}$ was purified by normal phase HPLC (Gilson 321 system; Luna $10 \mu$ silica (2) $250 \times 10 \mathrm{~mm}$ column, Phenomenex Inc.; $4 \mathrm{ml} \mathrm{min}^{-1}$ ) using isocratic elution with hexane-EtOAc $(2: 1)$. Both products showed identical ${ }^{1} \mathrm{H}$ NMR and CD spectra (Figure 2), as well as similar quasi-molecular ion peaks and retention times in LC-MS data. These data suggested that the absolute configuration of $\mathbf{1}$ was the same as that of $\mathbf{3}$.

Compound 2 was also obtained as a white amorphous powder that analyzed for the molecular formula $\mathrm{C}_{37} \mathrm{H}_{58} \mathrm{O}_{15}$ by HR-FAB-MS $\left((\mathrm{M}+\mathrm{H})^{+}=743.3860\right)$ in combination with ${ }^{1} \mathrm{H}$ and ${ }^{13} \mathrm{C}$ NMR data. The IR absorption bands at 1800 and $1709 \mathrm{~cm}^{-1}$ suggested the presence of a ketone and an $\alpha, \beta$-unsaturated carbonyl group. Analyses of the 2D NMR spectra of $\mathbf{2}$ allowed us to assign the structure of $\mathbf{2}$ as aldgamycin E, which was reported earlier. ${ }^{5}$ The ${ }^{1} \mathrm{H}$ NMR spectrum of 2 is very similar to that of aldgamycin E, although the reported structure of aldgamycin E was defined incompletely and its sugar linkage position was not determined. Two sugar units and an aglycone of 2 , as well as the optical rotation $\left(2-50.4^{\circ}\left(\mathrm{CHCl}_{3}\right)\right.$; aldgamycin E $\left.-56^{\circ}\left(\mathrm{CH}_{3} \mathrm{OH}\right)\right)$ are the same as those of aldgamycin $\mathrm{E}$. We, thus, proposed that the structure of $\mathbf{2}$ was identical to aldgamycin E. In addition to the ${ }^{1} \mathrm{H}$ NMR spectrum described earlier, the NMR data and the structure of compound 2 (Tables 1 and 2) need to be further described.

The absolute configurations of two sugar units of aldgamycin $\mathrm{E}$ were already described in an earlier literature. ${ }^{5,6}$ However, the aglycone of aldgamycin E was reported as a planar structure. In an earlier literature, the absolute configuration of GERI-155, a relative of chalcomycin, was assigned to be identical to that of chalcomycin on the similarities of their optical rotation values (GERI-155 $[\alpha]_{D}-75.5^{\circ}$; chalcomycin $[\alpha]_{\mathrm{D}}-43.5^{\circ}$ ) and NMR data. ${ }^{11}$ Similarly, compound 2 has a very similar optical rotation value as that of $4\left(2,-50.4^{\circ} ; 4\right.$, $\left.-29.0^{\circ}\right)$. This comparison is further strengthened when biosynthetic origins are considered. As these compounds were isolated from the same microbial culture, it is likely that compound $\mathbf{2}$ is produced through the same biosynthetic pathway as aldgamycin G, and is then reduced by an enoylreductase. ${ }^{12}$ On the basis of the spectroscopic data and biosynthetic considerations, the absolute configuration of 2 is proposed to be identical to that of aldgamycin $G(4)$. 
Table $1{ }^{1} \mathrm{H}(500 \mathrm{MHz})$ and ${ }^{13} \mathrm{C}(125 \mathrm{MHz})$ NMR data of compounds 1 and 2 in $\mathrm{CD}_{3} \mathrm{CN}$

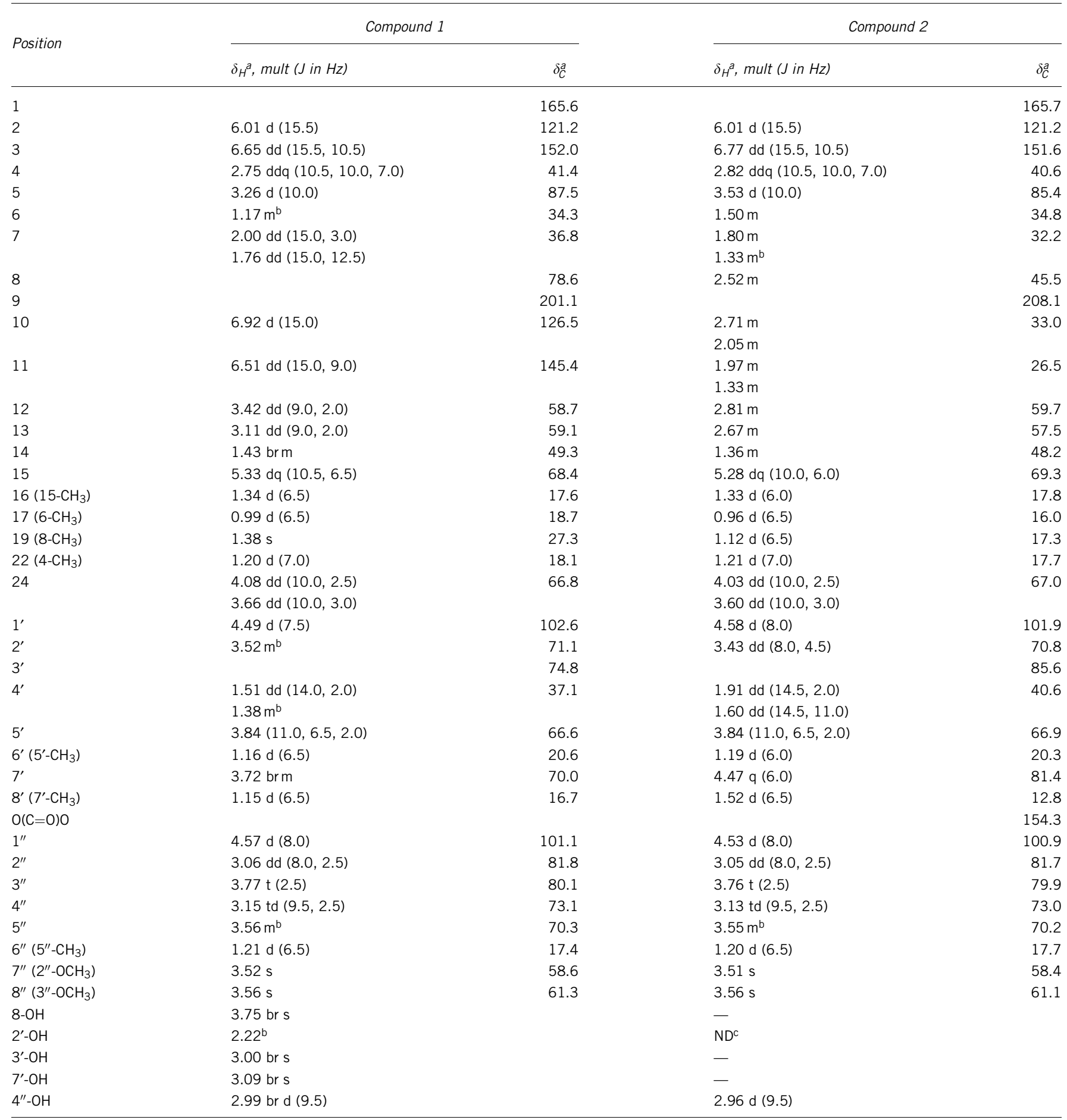

avarian unity: 500 ; reference standard: acetonitrile ( $\delta_{H}: 1.96$ p.p.m., $\delta_{\mathrm{C}}: 1.79$ p.p.m.).

bThe multiplicity of signal was unresolved by peak overlapping and the chemical shift was assigned by the analysis of HSQC and TOCSY spectra.

'The signal was not detected.

The antimicrobial activities of aldgamycin I (1), aldgamycin E (2), aldgamycin F (3), aldgamycin G (4) and chalcomycin (5) were measured using a MIC assay against Micrococcus luteus, Bacillus subtilis, Proteus vulgaris, Salmonella typhimurium, Aspergillus fumigatus, Trichophyton rubrum and methicillin resistant Staphylococcus aureus (Table 3). Ampicillin and amphotericin B were used as positive controls in each assay. Interestingly, all compounds showed selective antibacterial activ- ities against $M$. luteus and S. typhimurium. These compounds exhibited weak or no antimicrobial activities against B. subtilis, P. vulgaris, A. fumigatus, T. rubrum and MRSA as shown in Table 3.

\section{7', 4"-DI-O-P-BROMOBENZOYL-ALDGAMYCIN I}

${ }^{1} \mathrm{H}$ NMR $\left(500 \mathrm{MHz}\right.$, acetonitrile- $\left.d_{3}\right) \delta 7.98\left(4 \mathrm{H}, \mathrm{m}, \mathrm{Bz}^{a} 3-\mathrm{H}\right.$ and $3^{\prime}-$ $\mathrm{H}), 7.74\left(4 \mathrm{H}, \mathrm{m}, \mathrm{Bz}^{a} 4-\mathrm{H}\right.$ and $\left.4^{\prime}-\mathrm{H}\right), 6.91(1 \mathrm{H}, \mathrm{d}, J=15.5 \mathrm{~Hz}, 10-\mathrm{H})$, 
Table 2 Physicochemical properties of aldgamycins I (1) and E (2)

\begin{tabular}{|c|c|c|}
\hline & 1 & 2 \\
\hline Molecular weight & 730.8 & 742.8 \\
\hline$[\alpha]_{D}$ & $-19.1^{\circ}\left(\mathrm{c} 0.15, \mathrm{CHCl}_{3}\right)$ & $-50.4^{\circ}\left(\mathrm{c} 0.28, \mathrm{CHCl}_{3}\right)$ \\
\hline \multicolumn{3}{|l|}{ HR FAB MS $(\mathrm{m} / \mathrm{z})$} \\
\hline Found: & $753.3668(\mathrm{M}+\mathrm{Na})^{+}$ & $743.3860(\mathrm{M}+\mathrm{H})^{+}$ \\
\hline UV $\lambda_{\max } \mathrm{nm}(\varepsilon)(\mathrm{MeCN})$ & $218(22500)$ & $216(12900)$ \\
\hline $\mathrm{IR}(\mathrm{KBr}) v_{\max }$ & $3467,2975,2933,1709,1655,1629,1235,1083$ & $3457,2972,2934,1800,1709,1652,1083$ \\
\hline \multirow[t]{2}{*}{ Solubility } & Soluble: $\mathrm{MeOH}, \mathrm{MeCN}, \mathrm{CDCl}_{3}$ & Soluble: $\mathrm{MeOH}, \mathrm{MeCN}, \mathrm{CHCl}_{3}$ \\
\hline & Insoluble: Hexane, $\mathrm{H}_{2} \mathrm{O}$ & Insoluble: Hexane, $\mathrm{H}_{2} \mathrm{O}$ \\
\hline HPLC, Rt $(\min )^{a}$ & $14.2 \mathrm{~min}$ & $19.7 \mathrm{~min}$ \\
\hline
\end{tabular}

aLuna C18 (2) $\left(4.6 \times 150 \mathrm{~mm}, 5 \mu \mathrm{m}\right.$, Phenomenex) $10-100 \%$ acetonitrile/water for $30 \mathrm{~min}, 1.0 \mathrm{ml} \mathrm{min}{ }^{-1}$.
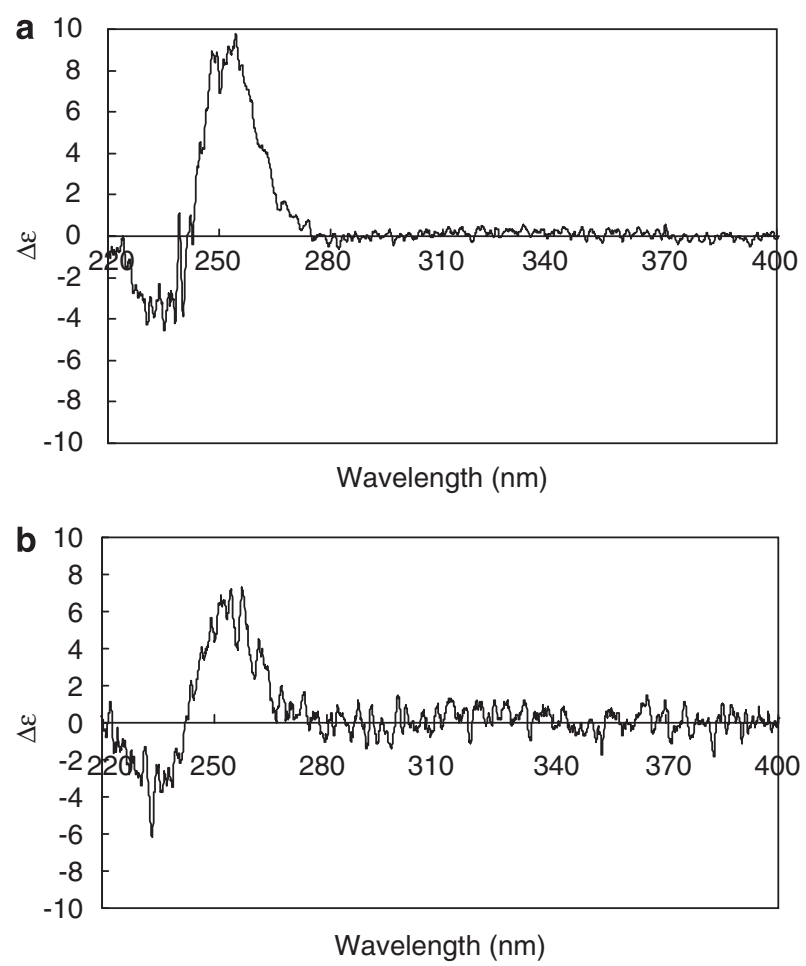

Figure 2 CD spectra of $7^{\prime}, 4^{\prime \prime}$-di-O-p-bromobenzoates of $\mathbf{1}$ (a) and aldgamycin $\mathrm{F}(\mathbf{b})$.

$6.64(1 \mathrm{H}, \mathrm{dd}, J=15.5,10.5 \mathrm{~Hz}, 3-\mathrm{H}), 6.52(1 \mathrm{H}, \mathrm{dd}, J=15.5,9.0 \mathrm{~Hz}, 11-$ H), $6.01(1 \mathrm{H}, \mathrm{d}, J=15.5 \mathrm{~Hz}, 2-\mathrm{H}), 5.33(1 \mathrm{H}, \mathrm{dq}, J=10.5,6.5 \mathrm{~Hz}, 15-\mathrm{H})$, $5.20\left(1 \mathrm{H}, \mathrm{m}, 7^{\prime}-\mathrm{H}\right), 4.73\left(1 \mathrm{H}, \mathrm{d}, J=10.0,2.5 \mathrm{~Hz}, 4^{\prime \prime}-\mathrm{H}\right), 4.69(1 \mathrm{H}, \mathrm{d}$, $\left.J=8.0 \mathrm{~Hz}, 1^{\prime \prime}-\mathrm{H}\right), 4.52\left(1 \mathrm{H}, \mathrm{d}, J=8.0 \mathrm{~Hz}, 1^{\prime}-\mathrm{H}\right), 4.11(1 \mathrm{H}, \mathrm{dd}, J=10.0$, $3.0 \mathrm{~Hz}, 24 \mathrm{a}-\mathrm{H}), 4.07\left(2 \mathrm{H}, \mathrm{m}, 3^{\prime \prime}-\mathrm{H}\right.$ and $\left.5^{\prime \prime}-\mathrm{H}\right), 3.91\left(1 \mathrm{H}, \mathrm{m}, 5^{\prime}-\mathrm{H}\right)$, $3.75(1 \mathrm{H}, \mathrm{s}, 8-\mathrm{OH}), 3.71(1 \mathrm{H}, \mathrm{dd}, J=10.0,3.0 \mathrm{~Hz}, 24 \mathrm{~b}-\mathrm{H}), 3.52(3 \mathrm{H}, \mathrm{s}$, $\left.3^{\prime \prime}-\mathrm{OCH}_{3}\right), 3.48\left(3 \mathrm{H}, \mathrm{s}, 2^{\prime \prime}-\mathrm{OCH}_{3}\right), 3.42(1 \mathrm{H}, \mathrm{dd}, J=9.0,2.0 \mathrm{~Hz}, 12-\mathrm{H})$, $3.30\left(1 \mathrm{H}, \mathrm{m}, 2^{\prime}-\mathrm{H}\right), 3.26(1 \mathrm{H}, \mathrm{d}, J=10.0 \mathrm{~Hz}, 5-\mathrm{H}), 3.22(1 \mathrm{H}, \mathrm{dd}, J=8.0$, $\left.3.0 \mathrm{~Hz}, 2^{\prime \prime}-\mathrm{H}\right), 3.12(1 \mathrm{H}, \mathrm{dd}, J=9.0,2.0 \mathrm{~Hz}, 13-\mathrm{H}), 3.08\left(1 \mathrm{H}\right.$, br s, $3^{\prime}-$ $\mathrm{OH}), 2.71(1 \mathrm{H}, \mathrm{m}, \mathrm{H}-4), 2.22\left(1 \mathrm{H}, \mathrm{br} \mathrm{s}, 2^{\prime}-\mathrm{OH}\right), 1.93(1 \mathrm{H}, \mathrm{m}, 7 \mathrm{a}-\mathrm{H})$, $1.82\left(1 \mathrm{H}, \mathrm{dd}, J=14.0,2.0 \mathrm{~Hz}, 4^{\prime} \mathrm{a}-\mathrm{H}\right), 1.71(1 \mathrm{H}, \mathrm{dd}, J=15.0,12.0 \mathrm{~Hz}$, 7b-H), 1.59 (1H, dd, $\left.J=14.0,10.0 \mathrm{~Hz}, 4^{\prime} \mathrm{b}-\mathrm{H}\right), 1.44(1 \mathrm{H}, \mathrm{m}, 14-\mathrm{H})$, $1.34\left(3 \mathrm{H}, \mathrm{d}, J=6.5 \mathrm{~Hz}, 15-\mathrm{CH}_{3}\right), 1.33\left(3 \mathrm{H}, \mathrm{s}, 8-\mathrm{CH}_{3}\right), 1.31(3 \mathrm{H}, \mathrm{d}$,
Table 3 Antimicrobial activities of compounds 1-5 (MIC, $\mu \mathrm{g} \mathrm{ml}^{-1}$ )

\begin{tabular}{cccccccc}
\hline $\begin{array}{c}\text { Micrococcus } \\
\text { Iuteus } \\
\text { IFC12708 }\end{array}$ & $\begin{array}{c}\text { Bacillus } \\
\text { subtilis } \\
\text { ATCC6633 }\end{array}$ & $\begin{array}{c}\text { Proteus } \\
\text { vulgaris } \\
\text { ATCC3851 }\end{array}$ & $\begin{array}{c}\text { Salmonella } \\
\text { typhimurium } \\
\text { ATCC14028 }\end{array}$ & $\begin{array}{c}\text { Aspergillus } \\
\text { fumigatus }\end{array}$ & $\begin{array}{c}\text { Trichophyton } \\
\text { HIC } 6094\end{array}$ & $\begin{array}{c}\text { MRSA } \\
\text { IFO 9185 }\end{array}$ & $\begin{array}{c}\text { ATCC } \\
43300\end{array}$ \\
\hline $\mathbf{1}$ & 3.13 & $>50$ & $>50$ & 6.25 & $>100$ & $>100$ & $>100$ \\
$\mathbf{2}$ & 0.78 & 12.50 & 50.00 & 1.56 & $>100$ & $>100$ & $>100$ \\
$\mathbf{3}$ & 0.78 & 25.00 & $>50$ & 1.56 & $>100$ & $>100$ & $>100$ \\
$\mathbf{4}$ & 1.56 & 50.00 & $>50$ & 1.56 & $>100$ & $>100$ & $>100$ \\
$\mathbf{5}$ & 0.78 & 12.50 & 12.50 & 1.56 & $>100$ & $>100$ & $>100$ \\
$\mathrm{~A}$ & 0.78 & 3.13 & 1.56 & 12.50 & - & - & 12.5 \\
$\mathrm{~B}$ & - & - & - & - & 1.56 & 1.56 & - \\
\hline
\end{tabular}

Abbreviations: A, ampicillin; B, amphotericin B.

$\left.J=6.0 \mathrm{~Hz}, 7^{\prime}-\mathrm{CH}_{3}\right), 1.22\left(3 \mathrm{H}, \mathrm{d}, J=6.0 \mathrm{~Hz}, 5^{\prime}-\mathrm{CH}_{3}\right), 1.21(3 \mathrm{H}, \mathrm{d}$, $\left.J=6.5 \mathrm{~Hz}, 5^{\prime \prime}-\mathrm{CH}_{3}\right), 1.18\left(3 \mathrm{H}, \mathrm{d}, J=7.0 \mathrm{~Hz}, 4-\mathrm{CH}_{3}\right), 1.17(1 \mathrm{H}, \mathrm{m}, 6-$ $\mathrm{H}), 0.99\left(3 \mathrm{H}, \mathrm{d}, J=6.5 \mathrm{~Hz}, 6-\mathrm{CH}_{3}\right)$. Carbon chemical shift in HSQC and HMBC spectra $\left(125 \mathrm{MHz}\right.$, acetonitrile- $\left.d_{3}\right) \delta 200.8(\mathrm{C}-9), 165.3$ (C-1), $164.8\left(\mathrm{Bz}^{a} 1\right.$ and $\left.1^{\prime}\right), 151.7(\mathrm{C}-3), 145.3(\mathrm{C}-11), 132\left(\mathrm{Bz}^{a} 4\right.$ and $\left.4^{\prime}\right), 128.0\left(\mathrm{Bz}^{a} 2\right.$ and $\left.2^{\prime}\right), 127.7\left(\mathrm{Bz}^{a} 5\right.$ and $\left.5^{\prime}\right), 131.5\left(\mathrm{Bz}^{a} 3\right.$ and $\left.3^{\prime}\right)$, 126.2 (C-10), 121.0 (C-2), $102.4\left(\mathrm{C}-1^{\prime}\right), 100.9\left(\mathrm{C}-1^{\prime \prime}\right), 87.8$ (C-5), 80.4 $\left(\mathrm{C}-2^{\prime \prime}\right), 78.2(\mathrm{C}-8) 77.5\left(\mathrm{C}-3^{\prime \prime}\right), 75.3\left(\mathrm{C}-4^{\prime \prime}\right), 74.1\left(\mathrm{C}-3^{\prime}\right), 71.4\left(\mathrm{C}-7^{\prime}\right)$, $70.5\left(\mathrm{C}-2^{\prime}\right), 68.2(\mathrm{C}-15), 67.8\left(\mathrm{C}-5^{\prime \prime}\right), 66.9(\mathrm{C}-24), 66.5\left(\mathrm{C}-5^{\prime}\right), 60.9$ (C-7"), 58.7 (C-13), 58.5 (C-12), $58.3\left(\mathrm{C}-8^{\prime \prime}\right), 49.0$ (C-14), 41.1 (C-4), 36.7 (C-4'), 36. (C-7), 27.2 (C-18'), $20.5\left(\mathrm{C}-6^{\prime}\right), 18.6$ (C-17), 17.8 (C-22), 17.6 (C-16), 17.1 (C-6), 17.1 (C-6 $\left.{ }^{\prime \prime}\right), 12.8$ (C-19). ${ }^{a} \mathrm{Bz}:$ p-bromobenzoyl group. ESI-MS $m / z 1095(\mathrm{M}+\mathrm{H})^{+}$.

\section{ACKNOWLEDGEMENTS}

This study was supported by the Korea Institute of Science and Technology institutional program, Grant number 2Z03020 and 2Z03100. We thank PhD candidate Choong-Sik Chae for antimicrobial activity at Seoul National University. We also thank the Center for Scientific Instruments at Kangneung National University for using LC/MS, and Dr Wendy Strangman at the University of British Columbia for scientific advices and English revision.

1 Haferburg, G. \& Kothe, E. Microbes and metals: interactions in the environment. J. Basic Microbiol. 47, 453-467 (2007).

2 Stierle, D. B., Stierle, A. A., Hobbs, J. D., Stokken, J. \& Clardy, J. Berkeleydione and berkeleytrione, new bioactive metabolites from an acid mine organism. Org. Lett. 6, 1049-1052 (2004). 
3 Stierle, D. B., Stierle, A. A. \& Patacini, B. The berkeleyacetals, three meroterpenes from a deep water acid mine waste Penicillium. J. Nat. Prod. 70, 1820-1823 (2007).

4 Kunstmann, M. P., Mitscher, L. A. \& Patterson, E. L. Aldgamycin E, a new neutral macrolide antibiotic. Antimicrob. Agents Chemother. 10, 87-90 (1964).

5 Achenbach, H. \& Karl, W. Investigations on metabolites of microorganisms, VI. On the structure of the antibiotic aldgamycin E. Chem. Ber. 108, 759-771 (1975).

6 Achenbach, H. \& Karl, W. Metabolites of microorganisms. VIII. Aldgamycin F, in a new antibiotic from Streptomyces lavendulae. Chem. Ber. 108, 780-789 (1975).

7 Mizobuchi, S., Mochizuki, J., Soga, H., Tanba, H. \& Inoue, H. Aldgamycin G, a new macrolide antibiotic. J. Antibiot. 39, 1776-1778 (1986).
8 Frohardt, R. P., Pitillo, R. F. \& Ehrlich, J. (Parke, Davis \& Co.) Chalcomycin and its fermentative production. U.S. 3,065,137 (1962).

9 Gurtler, V. \& Stanisich, V. A. New approaches to typing and identification of bacteria using the 16S-23S rDNA spacer region. Microbiology 142, 3-16 (1996).

10 Zitouni, A., Mathieu, F., Lebrihi, A., Sabaou, N. (National Polytechnic Institute of Toulouse) New Saccharothrix strain and its antibiotic derivatives, in particular mutactimycin and aldgamycin. Fr. 2870853 (2005).

$11 \mathrm{Kim}, \mathrm{S}$. D. et al. GERI-155, a new macrolide antibiotic related to chalcomycin. J. Antibiot. 49, 955-957 (1996).

12 Donadio, S., McAlpine, J. B., Sheldon, P. J., Jackson, M. \& Katz, L. An erythromycin analog produced by reprogramming of polyketide synthesis. Proc. Natl Acad. Sci. 90, 7119-7123 (1993). 